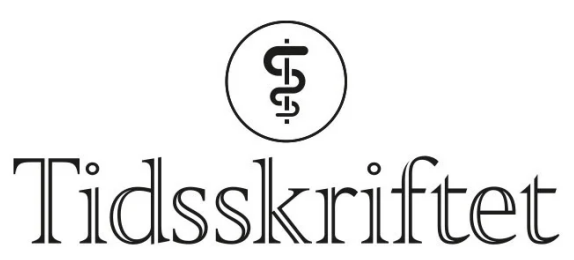

DEN NORSKE LEGEFORENING

\title{
Når hjernen undertrykkes
}

\author{
MEDISINEN I BILDER
}

\section{JOHANNES SVERRE WILLUMSEN}

johannes.sverre.willumsen@helse-mr.no

Nevrologisk avdeling

Molde sykehus

Johannes Sverre Willumsen er lege i spesialisering og konstituert overlege.

Forfatteren har fylt ut ICMJE-skjemaet og oppgir ingen interessekonflikter.

\section{ANNE-MARI HOLTE FLUSUND}

Radiologisk avdeling

Molde sykehus

Anne-Mari Holte Flusund er spesialist i radiologi og overlege

Forfatteren har fylt ut ICMJE-skjemaet og oppgir ingen interessekonflikter.

\section{GRO EDEL GULENG BLOMKVIST}

Avdeling for kirurgi og akuttmedisin

Molde sykehus

Gro Edel Guleng Blomkvist er spesialist i anestesiologi og overlege.

Forfatteren har fylt ut ICMJE-skjemaet og oppgir ingen interessekonflikter. 


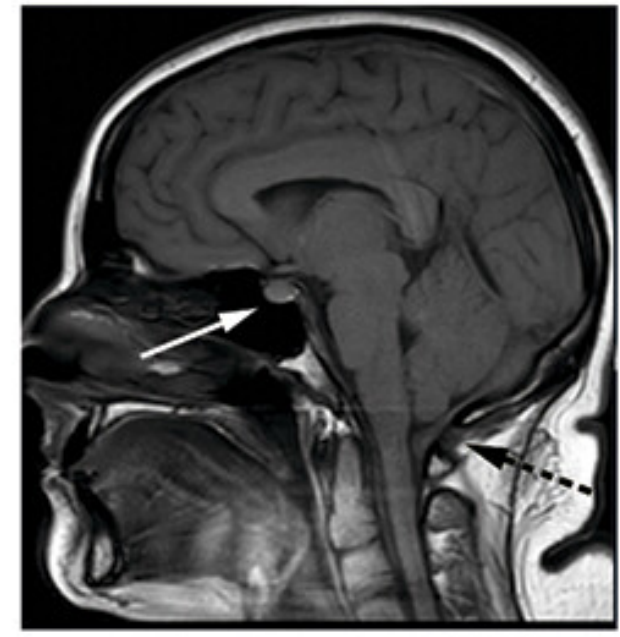

a

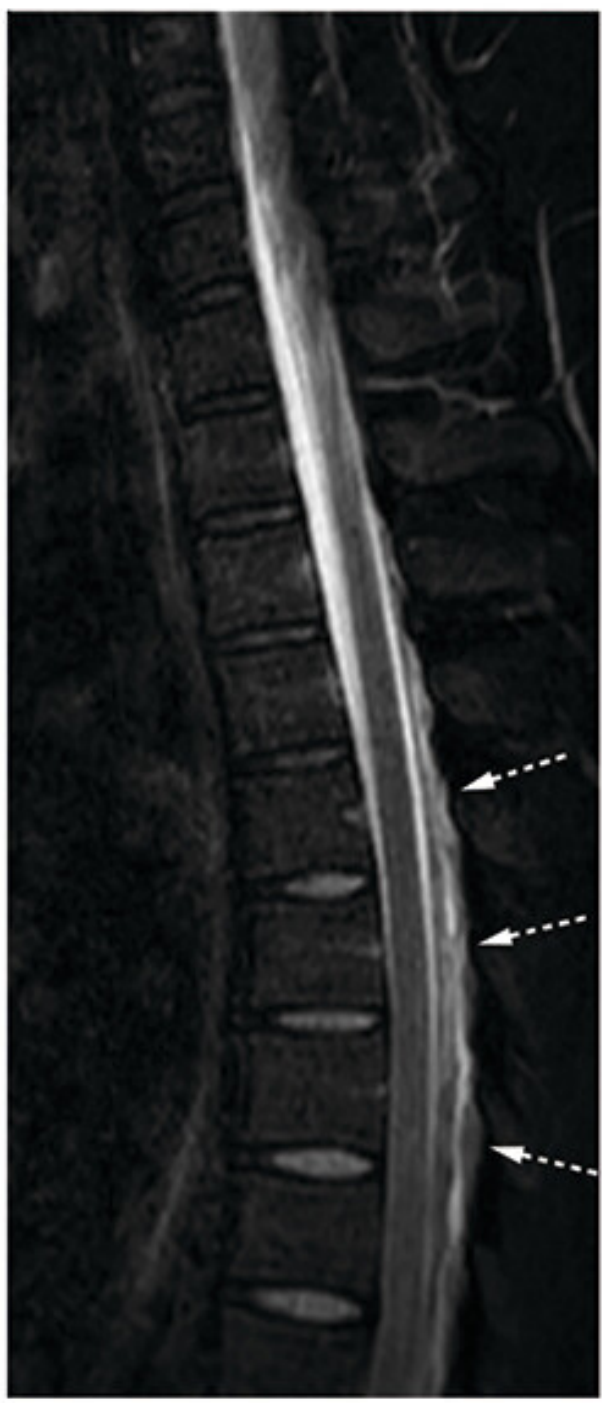

b

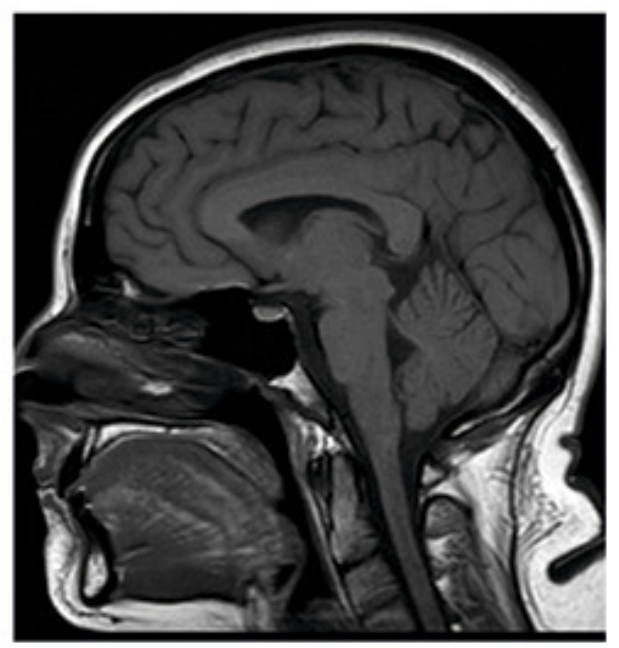

C

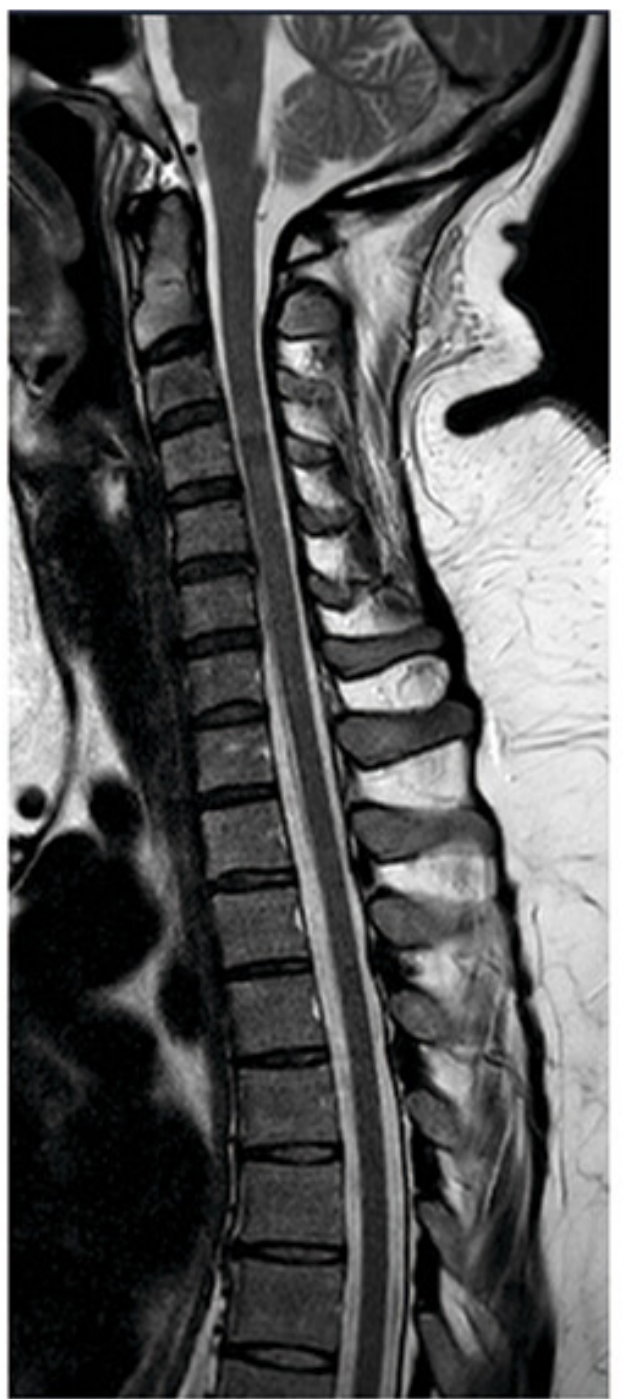

d

Bildene viser nevroaksen hos en tidligere frisk kvinne i 3o-årene. Sagittalt T1-vektet bilde av caput (bilde A) viser forstørret hypofyse (hvit pil) samt at hjernestammen og lillehjernetonsillene har sunket ned mot foramen magnum (stiplet svart pil). Sagittalt T2vektet, fettsupprimert bilde av cervikotorakalcolumna (bilde B) viser en epidural 
væskebrem i nivå Th4-Th9 (hvit pil). Det ble også påvist (ikke vist her) fortykkede meninger (FLAIR-serie) og en subdural væskebrem med blodprodukter langs tentoriet (susceptibilitetsvektet serie).

Kvinnen søkte legevakt grunnet nyoppstått interskapulær stivhetsfornemmelse med utstrålende smerter og nummenhet til overekstremitetene. I tillegg opplevde hun intens og pulserende hodepine ledsaget av svimmelhet, kvalme og oppkast. Hodepinen utviste forutsigbar variasjon med fullstendig lindring i liggende stilling og klar forverring ved stillingsendring.

MR-funnene og sykehistorien vekket sterk mistanke om spontan intrakranial hypotensjon (SIH). Pasienten ble i forkant av torakal epidural blodlapp, hvor $20 \mathrm{~mL}$ autologt venøst blod ble injisert i nivå Th7/Th8, behandlet med flatt sengeleie og peroral fenazon-koffein og acetazolamid. Prosedyren ble etterfulgt av 24 timers sengeleie med 30 graders senket hodeende (Trendelenburgs posisjon). Hun opplevde god effekt av behandlingen og kunne skrives ut til hjemmet etter tre dager. To måneder senere var hun i betydelig bedring og medikamentfri. Tre måneder etter blodlapp så man normaliserte intrakraniale forhold og kun en beskjeden mengde restvæske i epiduralrommet spinalt (figur C og D).

Spontan intrakranial hypotensjon er trolig underdiagnostisert og kjennetegnes av ortostatisk hodepine, som ved postpunksjonshodepine, og eventuelt andre nevrologiske symptomer som gjerne fluktuerer ved stillingsendring og/eller bevegelse. Ved mistanke om denne lidelsen bør pasienten henvises til nevrolog for vurdering av andre potensielt alvorlige årsaker til sekundær postural hodepine, som for eksempel cerebral sinusvenetrombose eller subaraknoidalblødning. Ledsagende symptomer som kvalme med oppkast, nakkesmerter og -stivhet sees hos omtrent halvparten av pasientene (1). Typiske MR-funn er diffus meningeal fortykkelse og kontrastoppladning, venøs blodopphopning og kaudal ektopi av hjernen, men også forstørret hypofyse som hos vår pasient. Radiologisk utredning muliggjør lokalisering av lekkasje- og intervensjonsstedet og kan avdekke komplikasjoner som subdural hematomutvikling.

En enkeltstående epidural blodlapp gir tilfredsstillende effekt hos over halvparten av pasientene. Hos pasienter som ikke responderer på det ovennevnte behandlingsregimet, vil man måtte vurdere målrettet kirurgisk intervensjon mot lekkasjestedet, som i noen tilfeller kan være vanskelig å identifisere.

Pasienten har gitt samtykke til at artikkelen blir publisert.

Artikkelen er fagfellevurdert.

\section{LITTERATUR}

1. D'Antona L, Jaime Merchan MA, Vassiliou A et al. Clinical presentation, investigation findings, and treatment outcomes of spontaneous intracranial hypotension syndrome. JAMA Neurol 2021; 78:32937. [PubMed][CrossRef]

Publisert: 22. november 2021. Tidsskr Nor Legeforen. DOI:10.4045/tidsskr.21.0447

Mottatt 27.5.2021, første revisjon innsendt 21.9.2021, godkjent 21.10.2021.

(C) Tidsskrift for Den norske legeforening 2023. Lastet ned fra tidsskriftet.no 26. april 2023. 